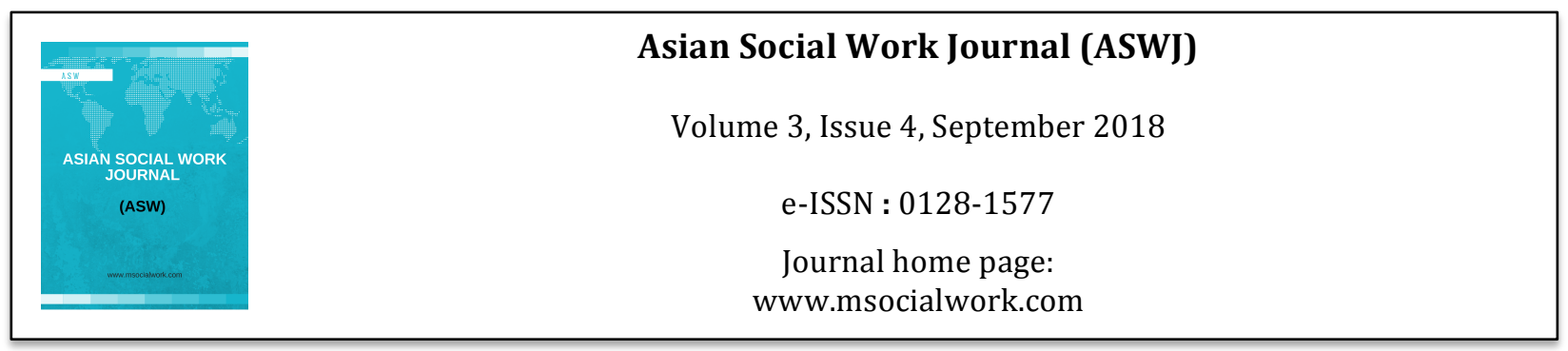

\title{
Knowledge and Skills of Social Workers in Handling Children in Conflict with Law in Indonesia
}

\author{
Ellya Susilowati ${ }^{1}$ \\ ${ }^{1}$ Bandung College of Social Welfare, Indonesia \\ Corrrespondence: Ellya Susilowati (ellya_stks@yahoo.com)
}

\begin{abstract}
This study aims to examine how the knowledge and skill of Social Workers in handling Children against Law (ABH) in Indonesia. Social Worker is a profession mandated by Law No. 11 of 2012 concerning the Juvenile Criminal Justice System has some duties, among others, such as assisting the recovery process and changes in Children behavior; giving consideration to law enforcement officers for handling children social rehabilitation; accompany the delivery of Children to their parents, government agencies or community institutions; and approach the community to be willing to accept the children in their social environment. This study used a qualitative approach with descriptive methods for six social workers who carried out tasks in Cianjur regency, West Java. Data collection techniques used interviews, observation and documentation studies. The results indicated that the knowledge and skills of Social Workers in carrying out the tasks of handling ABH still had some limitations, especially in the application of working skills with ABH. The recommendations of this study are: 1) Education and Training Center in the ABH training for Social Workers needs to increase knowledge and skills about social rehabilitation; 2) Children social workers conduct regular discussions and sharing on the competence of social work related to the handling $\mathrm{ABH}$.
\end{abstract}

Key words: knowledge and skills, social workers, conflict, children against law

\section{Introduction}

Social Worker is a professional Human Resources (HR) mandated by Law No. 11 of 2012 concerning Juvenile Criminal Justice System (SPPA) to deal with Children against the Law (ABH). Children dealing with the law are children in conflict with the law, those who are victims of criminal acts, and witnesses of criminal acts (Law Number 11 of 2012 concerning SPPA article 1 paragraph 3 and paragraph 4). The Law also states the purpose of the involvement of Social Workers in handling ABH in order to generate restorative justice. Marshal stated that restorative justice is a process that actively involves all parties (victims, perpetrators, family and society) to resolve disputes collectively, repair damages and losses caused by illegal behavior committed by a child (Marshall 1996, cited in McCold 1999:1). While diversion is an alternative process suitable for children in determining the responsibilities and actions to be given to $\mathrm{ABH}$ based on social, cultural, economic, psychological and educational backgrounds, and avoiding the formal justice process. (Government of the Philippines, Supreme Court 2002: 7).

The task of Social Worker according to Law No. 11 of 2012 is 1) provide consideration and advice at the investigation process; 2) submit reports on the results of investigation on Child Victims and Witness, 3) Guiding, helping, protecting and assisting the Children by conducting social consultations 
and restoring the confidence of the Children; 4) Provide assistance and social advocacy; 5) Assist the recovery process and changes in the children behavior; 6) Give consideration to law enforcement officers for handling children social rehabilitation; and 7) approach the community that they are willing to accept the children's return to their social environment.

Accordingly, Social Workers are required to have adequate competence in carrying out these tasks. Norman (1985) defines that competence is an ability to perform special tasks, actions, or functions successfully. Competence means covering efforts to transfer knowledge and skills into new situations, in preparing work planning, making innovation, overcoming non-routine activities, including personal effectiveness required in the field of work that is useful for dealing with co-workers, managers and customers. The task of Social Worker in carrying out ABH from the Ministry of Social Affairs of the Republic of Indonesia is to respond to the case against ABH, which includes services of: 1) emergency; 2) crisis intervention; 3) assistance in solving cases; 4) social rehabilitation; and 5) children and family encouragement services.

The number of children in conflict with law (ABH) handled by the Ministry of Social Affairs until 2016 is totaled 3,477 children, consists of: 1) 1,348 perpetrators, 2) victims of 1,952 children and 3) witnesses of 177 children. The handling of ABH conducted by Social Workers is based on the Ministry of Social Affairs policy by conducting: 1) ABH Handling Case Response, this activity is a type of emergency services or crisis intervention, including efforts to receive reports and case identification, rescue, recovery (medical/physical, psychological, social, and legal), assistance in undergoing legal processes in the community and/or the criminal justice system, and reintegrating children with their families and communities: 2) Children and Family Encouraging Meetings (TEPAK), are social rehabilitation programs aimed at children and families to improve $\mathrm{ABH}$ care.

West Java Province is one of the provinces with many cases of ABH. Based on data from West Java children in 2015, the number of children cases followed up to the court and the number of convicted children in West Java over the past three years indicated a decrease. This is partly due to the assistance and response to the cases of social workers in handling ABH. The West Java Provincial Social Service in 2016 recorded that there are 96 social workers widespread in 27 regencies/cities. Regarding these issues, the researcher is interested in examining how the competence of Social Workers in Handling $\mathrm{ABH}$ in West Java. One of the areas that contained the ABH case is Cianjur district, and the local Social Service had assigned Social Workers to handle ABH.

\section{Knowledge and skills of Social Workers.}

Zastrow (1999) stated that social worker is a profession that provide effective and constructive social services required to be based on knowledge, theoretical concepts, skills and important social values. Mastery in the framework of knowledge, skills and values can improve the competence of social workers in carrying out their duties safely. Competence can help to describe how a task can be carried out and used to plan, guide, and develop behaviors or performance of Social Workers.

Furthermore NASW in Zastrow (1999) identified the competence of social workers consisting of the following knowledge, skills and values:

i. Knowledge that social workers need to master in order to carry out social work practices effectively is the knowledge of: 1) theory and techniques of case work and group work; 2) services and community resources: 3) social service programs and their objectives: 4) community organizational theory and development of welfare services and health services; 5) basic socio-economic theory and politics; 6) ethnic racial groups, and other cultural groups in society, values and lifestyle, as well as issues in life; 7) sources of scientific and professional research that can support social work practices; 8) social planning concepts and techniques; 9) supervision in social work practices; 10) theory and concepts of personnel management; 11) general social and psychological statistics, as well as other research methods and techniques; 12) social welfare administration; k) social and environmental factors that influence clients; $13 \mathrm{j}$ ) 
assessment theories and methods and different psychosocial and diagnostic interventions; 14) theories and behaviors of social and organizational systems and methods for creating change; 15) theories and techniques of community organizations: 16) theories of human growth and development as well as social interaction and family interaction; 17) small group theory and behavior dynamics; 18) group interaction theory and therapeutic intervention; 19) crisis intervention theory and techniques; 20) advocacy theory and techniques; 21) ethical standards and professional social work practices; 22) teaching theory and techniques; 23) social welfare trends and policies; and 24) laws and regulations affecting social and health services.

ii. Skills that social workers need to master in order to support implementation of their duties effectively are skills in: 1) listening and understanding others, 2) conveying information and gathering facts to prepare social history, assessments and reports, 3) creating and maintaining professional supportive relationship and self-use in relationships, 4) observing and interpreting verbal and nonverbal behavior and using knowledge of personality theory and diagnostic methods, 5) building trust and engaging clients in an effort to overcome their own problems, 6) discussing sensitive emotional factors through a supportive way, 7) creating innovative solutions according to client needs, 8) determining the termination of supportive relationships and how to implement them, 9) interpreting the findings of research studies and professional literature, providing liaison interorganizational services, interpreting and communicate social needs to funding sources, the public and legislators, and 10) mediate and negotiate between parties in conflict.

iii. The value framework on which professional practice is based is: 1) commitment to the importance of individuals in society; 2) maintain confidentiality in dealing with clients; 3) commitment to social change to meet socially recognized needs; 4) separate personal feelings and needs in supportive relationships; 5) transfer knowledge and skills to others; 6) regard and respect for individual and group differences; 7) commitment to develop the client's ability to support himself; 8) endeavor on behalf of the client despite frustrating; 9) commitment to social and economic justice, and physical and mental well-being for all people; and10) commitment to personal and professional standards.

Mastery of competencies covering the framework of knowledge, skills and abilities and values underlying the practice of social work will facilitate social workers in carrying out their duties in order to support people to improve their social functioning as described in social work goals.

\section{Competence of Children Social Worker}

Social work is one of the main professions imposed by the society to help overcome the problems of children and families in meeting their needs (Petr, Christoper, 2004; Webb, Nancy Boyd, 2009). Children's issues must have special attention as individuals, family members, as well as part of their social environment. Professional social workers who work with children in addition to having general social work competencies obtained from higher education must also have special competencies to work with children as illustrated by O'Hagan (2007) on the core competencies of social workers who work in child care settings as follows: 1) Communication and exchange, by practice of forming and developing work relationships. Indicators of this activity are making initial contacts, explaining roles, agreements to control information, effective communication and recognizing differences in perspectives, values and goals. Output of this activity is writing down the first meeting plan; 2) Enable, by practice of working with client systems to help them identify their strengths in meeting their needs. Indicators of this activity are communicating appropriately, identify areas causing conflict, identify strengths and weaknesses of client system, describe judicial procedures and sources of legal advisors, and conduct client advocacy. Output of this activity is recording the handling of conflict issues carried out by social workers; 3) Assessment and intervention plan, the practice is that together with client system to take assessment on needs, responsibilities, rights and sources. Indicator of this activity is gathering important and relevant information, respect differences, balance differences in perspectives, needs and 
sources of problematic children, formulate activities' objectives and alternatives, identify sources and apply research results. Output of this activity is writing down an agreement on the care; 4) Intervention, the practice is to provide support and create change. The indicator is facilitating effective communication, help client system in conflict and stress management, negotiate the rules for further contact, respond to conditions' changes, assess effectiveness of intervention process. Output of this activity is to make records on implementation of the intervention.

Unwin \& Hogg (2012) in his book Effective Social Work with Children and Families suggests that Social Workers who work with children and families must have professional skills and standards of proficiency in terms of: 1) social work theories, values and methods for social work practices with children; 2) Applicable laws and policies relating to the handling of children and families: 3 ) understanding of the stages of child development: 5) communication skills and its improvisation; 6) assessment, of which social workers need to carry out dynamic roles in accordance with the framework assessment; 7) safeguarding, child protection and how to distinguish it; 8) perform critical analysis skills effectively; 9) make effective planning; 10) recording; 9) work within and around the organization; and 10) how to take care of themselves as social workers. Furthermore in NASW (2013) also explains that social workers working in the field of children's welfare often deal with conditions for making critical decisions while working in a stressful environment that includes severe accumulating cases despite limited supervision, training and support. Severe cases and heavy workloads often encourage social workers to leave their jobs. Explanation of a stressful environment relates to inadequate salaries, administrative workloads, fear of violence. Social workers also often encounter legal challenges while helping children who need protection. They have difficult task and problematic work environment in the children welfare system, therefore they must have competencies in order to facilitate the implementation of their duties. The social worker competencies required by NASW are as follows: a) having commitment to the value and professional ethics of social work as a guide to make ethical decisions without losing understanding of the uniqueness of children welfare practices; b) having knowledge gained from BSW or MSW level accredited education, c) must continually develop knowledge and skills to provide appropriate services to children and families involved in children welfare; e) advocate for improvements to systems and resources that will improve services to children and families; f) having interdisciplinary and interorganizational collaboration to support, improve and provide effective services to children and families; g) maintain confidentiality of clients; h) Provide services to children and families in their cultural context; i) conduct assessments; j) make intervention to ensure the welfare and security of children; $\mathrm{k}$ ) involving families in the process of service to children and reunification efforts; 1) involve children in meeting their own needs outside the institution and in the face of transition out of foster care; $\mathrm{m}$ ) make permanency planning for children who cannot live with their biological family; n) supervision; and o) carrying out administrative tasks related to service to children.

\section{Social Workers in the Law}

Social and legal work refers to social work practices and legal systems, including statutory law, laws relating to cases, legal institutions (courts, prisons, etc.), and legal professionals (lawyers, judges, paralegals, forensic experts, and professionals in dispute resolution alternatives). The law has a number of important roles in social work practices. (Allan E. Barsky, 2015). First, from an ecological perspective, the legal system is part of the client's social environment, as examples of children have been in the legal system, such as child protection, the juvenile criminal justice system. Social workers must recognize that the law is a regulating system to help direct child clients through more effective system and being able to advocate for legal reforms in order to improve between their clients and socio-legal environment. The law also regulates many relationships of interest with social work clients, including parent/child relationships. Thus, knowledge of the law must give practical understanding to practitioners about their clients' rights and responsibilities in various social relationships. Second, specific organizational laws regulate hospitals, schools, social assistance, correctional facilities, mental health facilities, and other social institutions. Specific legislation for organizations can dictate who is eligible for having the services, standards for recording, confidentiality, and other client rights. Social workers need to understand this law to ensure that the institution where they work adheres to the law, 
and being able to advocate changes in legislation to promote greater social and economic justice. Third, various laws govern the social work profession itself. Most states have licensing or accreditation laws that regulate social work practices, including who can practice and what standards of practice can be implemented legally.

\section{Handling ABH}

Handling ABH according to the guidelines of the Directorate of Child Social Rehabilitation (2015) is through cases response, which is a series of immediate and planned handling activities to provide assistance to $\mathrm{ABH}$. These activities can take the form of emergency services or crisis intervention. Emergency services are activities carried out to save children immediately from situations that are considered to endanger the safety of their lives. In such situations, children and families are often in a state of helplessness, and depend on external intervention to help them escape of the threat and save the child. While crisis intervention is a service activity carried out to help children and families deal with and resolve their problems due to crisis situations arising after the violence. This situation arises when the negative effects of violent events can no longer be overcome by the strength of the family. The task of the Social Worker in responding to the case includes:

i. Activities of emergency service are: a). Identify and receive complaints/reports on ABH cases; b). Identify child safety/security; c) Carry out rescue efforts/actions, coordinate with APH or other parties related to handling cases; d) Placement of children in temporary protection homes (safe houses, shelters); e) Provide support for meeting basic needs and psychosocial assistance as long as the child is placed in a shelter; f) Helping children and families get emergency medical services.

ii. Activities of Assistance Services are: 1) Helping children and families in the process of getting visum et repertum services or psychiatric post mortem (visum psikiatricum); b) Advocate to parties involved in handling child cases to ensure that the best interests of the child are considered; 3) Helping children and families get legal assistance services; 4) accompany children during the criminal justice process; 5) Facilitate the process of placing children in the LPKS according to the request of the Police, Prosecutor's Office, or the Court under the provisions and service standards; 6) accompany children in the mediation process; 7) conduct consultations/education for children $\&$ families related to the undergoing legal process

iii. Activities of Social Rehabilitation Services are: 1) conduct guidance and counseling activities for children; 2) include children in activities of religious education and moral development; 3 ) connecting children with general education services and/or vocational skills training; 4) have or connect children with psychosocial therapy services; 5) assist the child while undergoing court decision in the form of action; 6) accompany the child while undergoing and fulfilling the conditions in the diversion agreement.

iv. Activities of Child and Family Encouragement Services are: 1) Conduct family counseling; 2) Children and families encouragement gathering; 3) provide Conditioning Cash Transfer (CCT) for children as a companion to advanced social rehabilitation services; 4) help children access skills education services; 5) Approach to and collaboration with schools/educational institutions to help children get education and adapt; 6) approach, coordination, and seek support from community leaders and members of the closest community of children to strengthen the acceptance of children in families and communities; 7) Monitor and assist the process of encouraging positive behavior and adaptation of children in their families, schools and environment. 


\section{Research Method}

This study used a qualitative descriptive approach aimed at obtaining information about existing conditions (Mardalis, 1999: 26). The design of this study is considered appropriate to describe the competence of Social Workers in carrying out the tasks of Social Workers in handling ABH. This research was conducted in Cianjur Regency, West Java. The main informants of this study are Professional Social Workers who are carrying out the task of responding to cases of children dealing with the law. This informant was determined purposively, which is determining the informant with certain goals and considerations by determining certain criteria. These criteria include professional social workers, which is Sakti Peksos, who are carrying out the task of responding to ABH cases. Those who meet these criteria are six Social Workers in Cianjur district, who have become Social Workers between 1 and 7 years, and they have handled between 2 and 10 cases. Data collection techniques used in this study was in-depth interview techniques, observation, and documentation studies. Draft of Validity of Data Verification as stated by Moleong (2001: 173) used: a) credibility, b) transferability c) dependability, and d) confirmability. Data checking was carried out by Extension of observation, increasing persistence, triangulation, adequacy of references, detailed descriptions, and audit. Draft of Analysis Design was done by unit processing (Unityzing), categorization, and interpretation of data.

\section{Results}

The number and type of cases handled by Social Workers until November 2016 were 24 cases. The most number and type of $\mathrm{ABH}$ cases were sexual violence, which were six (8) cases, the next ones were five (5) cases of motor theft and five (5) cases of brawl. In addition, there are also four (4) cases of sexual abuse against children. Children as victims of violence were 9 children and as many as 15 children of perpretators.

\section{The process of handling ABH cases}

The Office of Social Strans of Cianjur District revealed that the process of handling ABH in Cianjur District had been accompanied by social workers according to the mandate of Law Number 11 of 2012 concerning SPPA. From the 24 handled cases up to November 2016, there were contributions from Social Workers Assistance. In detail, the types of processes for handling ABH cases are: 1) Diversion (6 cases); 2) Court proceedings (2 cases); 3) Litigation Process (9 Cases); 4) Post Litigation Process (7 cases). From these data, it is evident that six cases have been resolved through diversion that the child (the perpetrator of the case) avoids the judicial process. In Article 1 point 7 of the SPPA Law it is stated that diversion is the transfer of settlement of the Children case from criminal justice process to a process outside the criminal justice. The implementation of Diversion must have the consent of the child as a criminal, parent or guardian and requires cooperation and the role of the community in connection with the existence of programs such as supervision, guidance, recovery, and compensation to victims. Therefore, Social Workers play a very important role in mentoring, mediation, including strengthening the capacity of children and their families. Furthermore, one social worker informant stated that during the handling of $\mathrm{ABH}$ case so far uses a case management approach. While other social worker informants put forward the handling of cases using the stages of social worker practice.

\section{Knowledge and skills of social workers in handling $A B H$}

Social Workers in carrying out the handling of $\mathrm{ABH}$ require special competencies; therefore, the Ministry of Social Affairs through the Training Center has trained Social Workers who are members of the Social Workers Service Unit (Satuan Bakti Pekerja Sosial-Sakti Peksos) about handling ABHfor about one month. The number of Social Workers in Cianjur district who had received ABH training was three people, which was Sakti Peksos, while the other three social workers had not received ABH training but had attended case management training facilitated by Save the Children. Based on the results of the interviews, all the informants found that they did not understand the stages of the response of $\mathrm{ABH}$ case in accordance with the guidelines of the Ministry of Social Affairs' Directorate 
of Child Social Welfare, all the cases handled were based on the stages of social work practices and case management. Social Worker Competence in handling ABH cases is based on the framework of knowledge, skills and value of social work. All informants expressed the knowledge and skills that underlie implementation of their duties based on the guidelines of the Ministry of Social Affairs in handling $\mathrm{ABH}$. The following are findings of research on knowledge and skills used by Social Workers in handling $\mathrm{ABH}$ cases in emergency services, assisting in case resolution, social rehabilitation services and child and family encouraging services.

\section{i. $\quad$ Emergency Services}

Emergency services in the handling $\mathrm{ABH}$ are activities carried out to save children immediately from situations that are considered to endanger their life, including medical and psychosocial first aid. All Social Workers informants have carried out emergency services in handling ABH. Even some informants define emergency services as case response services, that the answers on knowledge and skills used are more complete. The knowledge framework and values are used as follows:

The underlying knowledges in conducting emergencies is: a) social work practices (as put forward by 4 informants), which is the stages of social work practices as knowledge used in emergency services; b) Child development, that in responding to the case pays attention to the child's age; c) Juvenile criminal justice system (SSPA) relating to the investigation process; d) Reference agencies, this is important because there may be cases of children who need immediate assistance from other services, such as health; e) child safety and security; f) handling of children; and 8) Assessment. This is as stated by one of the ES informants as follows: "... when understanding the age of the children we deal with, thus we also regulate how to deal with the child". However, there is some knowledge that has not been brought up, including relating to safeguarding or relating to child safety and safety. However, in terms of emergency services related to the concept of crisis intervention, the informants did not explain it. Malcompayne (2005) describes the theory of social work practices about crisis intervention and the task center that social work must do when dealing with crisis situations including emergencies.

The skills applied by social worker informants in emergency services for handling children so far are: a) building communication and relationships with children, that children have a 'trust' to social workers; b) networking skills used to provide emergency relief processes; c) assessment skills to get fast data, but assessment skills are here; d) Interviews mainly to open talks with children; and e) coordination with various parties. Assessment skills used in emergency services using assessment tools developed by management.

Knowledge and skills underlying social workers in handling this case are obtained from college at the Bandung Social Welfare High School.

\section{ii. $\quad$ Assistance in solving cases}

One of the tasks of Social Workers in handling ABH is to provide assistance in solving cases. Assistance carried out by social worker informants so far are: 1) accompanying children during criminal justice process; 2) assistance during diversion process. Activities carried out by social workers here are: 1) compiling social reports as consideration for the police to make decisions about the status of perpetrators; 2) Coordination with the perpetrator's family, the victim's family, government officials in the neighborhood where the perpetrator or victim lives, the school, religious leaders in the neighborhood where the perpetrator lives; 3) Following the diversion decision making process in the case of the perpetrator; 4) Negotiations with the victim's family to accept diversion; 5) Advocate to the school that children remain in the school; 6) Assisting the agreements between the families of the victims and the perpetrators as well as families of the perpetrators in achieving diversion status. 
The framework of knowledge and skills of social workers used in assisting in the resolution of cases is:

a) Framework of knowledge

- Child assistance. This knowledge is required and must be mastered by social workers about how to assist children. Special assistance was obtained from training on case management and good parenting organized by Save the Children in April 2016.

- Children dealing with the law. Social workers in providing assistance must master $\mathrm{ABH}$, especially with regard to policies related to $\mathrm{ABH}$, namely Law No. 11 of 2012 concerning the Juvenile Criminal Justice System (SPPA).

- Child development. Knowledge of child development is an important aspect in assistace of children's problems that the facilitator responds according to the age of the child's development. Social work, knowledge of social work is an aspect that needs to be known by social workers in carrying out professional help processes in the mentoring phase. However, the knowledge of social work put forward is related to the methods and stages of social work assistance. However, all informants did not specifically mention social work practices with children.

All this knowledge was obtained while studying at the Bandung Social Welfare School.

b) Skills

The skills used by social worker informants in assistance: Communication, this skill is used to carry out assistance tasks. Communication is carried out with children, families and with related parties in handling $\mathrm{ABH}$; b) building trust with accompanied clients: c) Making social reports, these skills are making reports about identity, chronological cases. ; 4) Advocacy, the skill is used to defend ABH rights such as the right for education; 5) Negotiation, this skill is used to persuade the victim's family to approve decision and assistance in the diversion process; 6) Brokering, this skill is used when helping perpretators in accessing the required services, such as placement of perpretators at the Bambu Apus Bina Remaja Social Institution for vocational training; 7) foster relationships that have been formed with children and families who are assisted. These skills can be obtained when studying at the Social Welfare School (STKS).

From this explanation, it indicates that social workers have sufficiently used the knowledge and skills of social workers in the implementation of assistance services for $\mathrm{ABH}$, including child social work practices.

\section{iii. Social Rehabilitation Service}

Almost all social worker informants in this study stated that they did not carry out all stages or mechanisms for handling $\mathrm{ABH}$ in accordance with the existing guidelines. Even some informants said they did not carry out social rehabilitation in handling cases, because most of the handled cases were more quickly terminated through diversion without doing initial social rehabilitation.

However, most of them stated that social workers who worked in handling $\mathrm{ABH}$ cases as stated by Henry Kesser and Scott Allan must own the knowledge and skills about social rehabilitation in the handling of $\mathrm{ABH}$. The following is an explanation of Social Worker informants:

Knowledge that social worker must have relating to social rehabilitation is: a) Social Work, is the underlying knowledge in social rehabilitation, and this is stated by all informants; b) Behavioral changes, especially those related to technical techniques for problem solving such as: behavior change, counseling, communication and good parenting (Positive Disipline Everyday Parenting) are social rehabilitation knowledge in handling $\mathrm{ABH}$. This knowledge was obtained from studying 
at STKS, and part of the training at Save the children. However, the Ministry of Social Affairs does not provide special strengthening related to social rehabilitation.

Some of the skills used in social rehabilitation as stated by conducting social rehabilitation are the same as the skills at other stages, namely: a) communication; b) Assessment; c) methods of individual and family social work; d) counseling; e) case management; f) reference; g) termination.

Some informants hoped to get more specific knowledges and skills related to social rehabilitation of knowledges and skills for ABH management, such as special counseling for children, behavior change therapy for $\mathrm{ABH}$ social rehabilitation.

\section{iv. Child and family encouraging services}

Child and family encouraging services are stages of $\mathrm{ABH}$ case response service according to the program of the Ministry of Social Affairs, and only two Social Workers (Sakti Peksos) informants answered about child and family encouraging services. While other Social Workers are more aware of Social Workers, some informants stated that child and family encouraging services are part of the $\mathrm{ABH}$ handling program. The activities carried out by three Social Workers informants in this service were: family counseling, Child and Family Encouraging Gathering (TEPAK), which contained activities on good parenting, Child Development Session. Knowledge and skills that support the work of social workers are:

Knowledge related to: a) behavior change used to direct clients to behavior that can be accepted religiously, socially and culturally; b) Counseling; c) Good Parenting, this knowledge is very important as it is to improve childcare; d) source systems, this knowledge is important to access families and children with the required resources.

The framework of skills used in child and family encouraging activities are counseling, networking/accessing the source system, social work with the community, trust building, negotiation, case management and teaching to train parents.

This source of knowledge was obtained from college and training from save the children. Skills related to child and family encouraging services implemented so far are more concerned on implementation of the Ministry of Social program, not specifically related to the needs of child and family encouraging services for $\mathrm{ABH}$. This is due to limited competence of social workers in implementing child and family encouraging services for $\mathrm{ABH}$.

\section{Discussion}

Social Workers in handling $\mathrm{ABH}$ are required to have special competence in the $\mathrm{ABH}$ handling process as formulated by the ABH Handling Case Response guidelines from the Directorate of Child Social Rehabilitation of the Ministry of Social Affairs, namely in the process of performing services of 1) emergency; 2) crisis intervention; 3) assistance in solving cases; 4) social rehabilitation; and 5) child and family encouraging services.

Based on the results of the study, it is evident that knowledge and skills underlying Social Workers' competence in handling ABH cases are still based on the competencies of Social Work in general, not specific based on the needs of each stage of handling cases for children dealing with the law. Some references discussing the role of workers relating to children dealing with the law states that social workers must understand about social work practices and the legal system, including the applicable laws and regulations, the law of handling cases, legal institutions (courts, prisons, etc.), and legal professionals (such as lawyers, judges, paralegals, forensic experts, and professionals in dispute resolution alternative) (Barsky A E. 2015). Indonesia has a policy related to the legal system and policies that protect children dealing with the law, and this has been known by most Social Workers, 
but not mastered in depth. In detail, the discussion about the knowledge, skills and values by the Social Sciences Team in responding to $\mathrm{ABH}$ cases are as follows.

\section{Knowledge}

Social Workers (Sakti Peksos) have knowledge of clients and social work (Knowledge of clients (children), namely children's rights, child development, parenting or good parenting. Other knowledge is related to the legal system and among others concerning Law No. 11 of 2012 on Juvenile Criminal Justice System (SPPA). Sakti Peksos has explained about SPPA, but it does not describe in detail related to the process of assistance in diversion, as well as assistance in court, which should be carrried out in assisting child cases in the restorative justice process as stated in Law 11 in 2012. Social Workers' Service has also received training on ABH for almost a month at the Ministry of Social Education and Training Center, and the Social Workers Team should have understood the legal system, that the Sakti Peksos can carry out the case response stages, especially the stage of professional handling of cases. Other knowledge in the legal system that must have is the network in the legal process.

Knowledge of Child Social Work owned by Sakti Peksos is about case management, child assistance and communication. In assisting children, it has been adjusted to the knowledge of child development. This is in accordance with what was stated by Petr (2004) about the combanting adulcentrism perspective. However, in theory, they do not understand this, as in general, the Social Workers do not understand the perspective of the practice of social work with children integratively as stated by Petr.

In the $\mathrm{ABH}$ emergency service process, Social Workers lack knowledge about crisis intervention for the handling of $\mathrm{ABH}$. The answers about knowledge related to emergency services, are about children's rights, child development, SPPA and assessment. Malcompayne (2005) describes the theory of social work practices about crisis intervention and the task center that social work must do in dealing with critical situations including emergencies.

In assisting for the completion of $\mathrm{ABH}$ cases, child social workers have had sufficient knowledge, which is related to the assistance of ABH children and child development. This is in line with what was stated by NASW (2013), and Unwigh (2013) that this knowledge is required and must be mastered by social workers about how to assist children.

The skills possessed by Sakti Peksos in servicing the stages of handling ABH in general are the same, that Sakti Peksos also lacks specific skills at each stage of handling ABH which are: a) building communication and relationships with children, that the child gains 'trust' for social workers; b) networking skills used to provide emergency relief processes; that is done with the police, medical, but the Social Worker has not explained in detail the networking skills with other law enforcement officials such as in court; c) assessment skills to obtain fast data; d) Interviews mainly to open talks with children; and e) coordination with various parties. Some Sakti Peksos have also used assessment tools to figure out family conditions, such as the genogram and ecomap. However, Social Workers are less skilled in conducting skills for social rehabilitation services for ABH in accordance with the conditions and age of the child. Some limitations of Social Workers in carrying out ABH rehabilitation skills are about lack of skill in implementing techniques of child behavioral changes. This is necessary because with the restorative justice approach, Social Workers must accompany children and families for better behavioral change.

\section{Skills}

The skills possessed by Sakti Peksos in servicing the stages of ABH handling in general are the same, so that Sakti Peksos also lacks specific skills at each stage of ABH's handling of: a) building communication and relationships with children, this is done so that the child has' trust 'to social workers; b) networking skills used to provide emergency relief processes; that is done with the police, health but the Social Worker has not explained in detail the networking skills with other law enforcement officials such as in court; c) assessment skills to get fast data; d) Interviews mainly to 
open talks with children; and e) coordination with various parties. Some Sakti Peksos have also used assessment tools to find out family conditions, such as the genogram and ecomap. however, Social Workers are less skilled in conducting skills for social rehabilitation services for $\mathrm{ABH}$ in accordance with the conditions and age of the child. Some limitations of Social Workers in carrying out ABH rehabilitation skills are about lack of skill in implementing child behavior change techniques. This is necessary because with the restorative justice approach, Social Workers must accompany children and families for better behavior change.

Meanwhile, Social Workers emphasize case response emergency services and assist children in the diversion process. Obstacles to Social Workers' Attempt in conducting Social Rehabilitation is that variations in the characteristics of children varying in terms of age and condition, while Social Workers are still not skilled at carrying out social rehabilitation techniques on age. Besides, they also face other various limitations, such as inaccessible locations/places, including the limited place to carry out social rehabilitation. However, it does not reduce the substance of social rehabilitation and is able to adjust to the existing conditions and limitations. This is in accordance with the components of social rehabilitation, namely: person, problem, place, and process. This means that social workers in carrying out social rehabilitation activities need to pay attention to clients with all their uniqueness/characteristics, problems that the clients have to deal with, places that allow social rehabilitation and the process or mechanism/stages of social rehabilitation itself. Hence, the knowledge, values and skills possessed by social workers are expected to help solve the problems faced by child clients optimally.

Skills in assistance in solving the children's cases are also important aspects in handling ABH. Sakti Peksos has had specific skills in this process mainly related to 'child assistance', either mentoring diversion processes at the event level to the diversion process at the court level that children are protected. Limitations of social workers in providing assistance are also due to limited supervision from supervisors. Another problem is the funding for ABH. However, some social workers have demonstrated their advocating skills in defending $\mathrm{ABH}$ rights such as education rights. Social Workers have also begun to engage in negotiations to persuade victims' families to approve decisions and assistance in the diversion process.

The skills that Social Workers rarely explain in the findings of this study are skills in making reports, as their social reports are indispensable in the process of handling children against the law (Barsky A E. 2015; NASW, 2013; Unwin \& Hogg, 2012).

\section{Conclusions and Recommendations}

Social Workers have carried out the task of handling the ABH case based on knowledge and skills of social work practices in general. Three Social Workers, among others, have had special competencies related to $\mathrm{ABH}$ assistance, such as knowledge about policies related to $\mathrm{ABH}$, which is Law No. 11 of 2012 concerning SPPA, knowledge of Social Work, and child development. This is consistent with what Unwin \& Hogg (2012) and NAWS (2013) have stated. While the skills used by informants of Social Workers in the process of responding to ABH cases are about communication skills, assessment, and only two informants stated about social reporting skills. In carrying out the task of assisting in the resolution of cases, several social workers stated that they had assisted the child in the process of obtaining visum et repertum services, assisting the child while undergoing criminal justice process, facilitate the process of placing children in the LPKS according to the request of the Police, Prosecutor's Office, or the Court under the provisions and standards services, and assisting children in the mediation process. There are several differences in knowledge and skills applied in the implementation of this task, including related to networking, lobbying, and coordination with various parties related to child cases.

Knowledge and skills that are still limited in the implementation of $\mathrm{ABH}$ is in carrying out the tasks of social rehabilitation services, some social workers convey that they have no social rehabilitation for the handled cases. By consideration of the cases handled mostly through diversion and returned them to 
parents without initially doing social rehabilitation. They also still have limitations to carry out social rehabilitation techniques. While the task of handling $\mathrm{ABH}$ according to the Convention on the Rights of the Child is recovery and rehabilitation. Other knowledge and skills related to child handling that informants did not bring it up related to: 1) safeguarding, and 2) performing critical analysis skills effectively. Based on the conclusion of the study, it is recommended that: 1) the Education and Training Center in the $\mathrm{ABH}$ training for Social Workers needs to increase knowledge and skills about social rehabilitation for ABH; 2) Social Worker Supervisors periodically supervise social work for the implementation of social worker duties in handling $\mathrm{ABH}$. Recommendations for further research are about social worker supervision in handling $\mathrm{ABH}$.

\section{References}

Allan E. Barsky. (2015). "Social work and the law" refers to the interface between the practice of social work and the legal system, including statutory law, case law. http://www.oxfordbibliographies.com/view/document/obo-9780195389678/obo9780195389678-0024.xml. Diakses tanggal 1 May 2017. Jam 15.30.

Allan W Scott. (1976). Rehabilitation: A Community Challenge. London. Chapman \& Hall Limited Barsky, Allan EAuthor (2009): 69-92 . The Legal and Ethical Context for Knowing and Using the Latest Child Welfare Research. InformationView Profile. Child Welfare; Arlington88.2 . http://search.proquest.com/socialsciences/docview/213807245/fulltextPDF/C47DFE38ADA4A 90PQ/2?accountid=50790. Diakses pada tanggal 1 May 2017. Jam 7.28.PM

Blok, W. 2012. Core Social Work. International Theory, Values dan Practice. London and Philadelphia: Jessica Kingsley Publishers.

Boyd Webb, Nancy (2009) Praktek Pekerjaan Sosial dengan Anak. Pustaka Societa

BP3AKB, Profil Anak Jawa Barat tahun 2015

Colby, I. \& Dziegielewski, S.F. 2008.Introduction to Social Work: The People's Profession. Lyceum Books, Inc

Cole, M., Cole, R,S. \& Lightfoot, C.(2005 ) The Development of Children. Fifth edition. New York . Worth Publishers.

Katherine van Wormer. (2003). Restorative Justice: A Model for Social Work Practice with families. Families in Society; Milwaukee 84.3 (Jul-Sep 2003):

Dubowit, H. \& Depanfilis, D. (2000). Child protection practice . London. Sage Publication

Frost, N.\& Parton, N. (2009). Understanding children's social care. Politics, Policy and practice. Sage

Harvard University.Competency Dictionary. ttps://www.campusservices. Harvard.Edu

Holland, Sally (2004). Child And Family Assessment In Social Work Practice.

Malcompayne (2005). Modern Social Work Theory. Palgrave Macmillan

NASW Center for Workforce Studies: http://workforce.socialworkers.org

NASW. 2013. NASW Standards for Social Work Practice in Child Welfare.

Norman, GR. (1985). Assessing Clinical Competence. New York: Springer; 330-341.

O'Hagan, K. 2007. Competence in Social Work Practice: A Practical Guide For Students and Proffesionals.(2nd edit). Philadelphia: Jessica Kingsley Publishers

Petr, Christopher, G. (2004). Social Work with Children and their Families. New York. Oxford University Press

Robbie Welch Christler Tourse; Mooney, Jean F; Kline, Paul; Davoren, Jeanne. Journal of Social Work Education; Washington 41.3 (Fall 2005): 457-477.

Schroeter, K. (2008). Competence Literature Review. CCI

Soetodjo, W. (2006). Hukum Pidana Anak. Bandung, PT. Refika Aditama.

Undang-undang Nomor 11 tahun 2012 tentang Sistem Peradilan Pidana Anak

Unwin, Peter \& Hogg, Rachel (2012). Effectice Social Work with Children and Families. A Skill Handbook. London. Sage Pubication

Zastrow, C.H. (1999). The Practice of Social Work. California: brooks/Cole Publishing Company 